\title{
Piscirickettsia salmonis gen. nov., sp. nov., the Causative Agent of an Epizootic Disease in Salmonid Fishes $\dagger$
}

\author{
J. L. FRYER, ${ }^{1 *}$ C. N. LANNAN, ${ }^{2}$ S. J. GIOVANNONI, ${ }^{1}$ AND N. D. WOOD ${ }^{1}$ \\ Department of Microbiology, Oregon State University, Nash Hall 220, Corvallis, Oregon 97331-3804, \\ and Laboratory for Fish Disease Research, Department of Microbiology, Mark O. Hatfield \\ Marine Science Center, Oregon State University, Newport, Oregon $97365-5296^{2}$
}

\begin{abstract}
A novel intracellular pathogen morphologically similar to the ehrlichiae has been isolated in cell culture and identified as the cause of an epizootic disease of salmonid fish. Like the ehrlichiae, the salmonid pathogen, designated strain LF-89, replicates within membrane-bound cytoplasmic vacuoles in host cells. This agent is the first with characteristics of this type to be isolated from a fish. Analysis of the LF-89 16S rRNA indicated that, unlike the ehrlichiae, LF-89 is a gamma proteobacterium distantly related to Coxiella burnetii and perhaps Wolbachia persica. A new genus and species (Piscirickettsia salmonis gen. nov., sp. nov.) are proposed for this organism, with ATCC(R) VR 1361 as the type strain.
\end{abstract}

An obligately intracellular bacterium, strain LF-89, has been isolated (5) and identified as the etiologic agent (6) of an epizootic disease resulting in extensive mortality among salmonid fish reared in the Pacific Ocean coastal waters of South America. Losses to this disease were reported in 1989 to range from 30 to $90 \%$ of the coho salmon (Oncorhynchus kisutch) held in seawater netpens at many sites in southern Chile near Puerto Montt (1).

Initially the disease was thought to be confined to coho salmon, but infectivity studies with the isolated organism demonstrated pathogenicity for both coho and Atlantic salmon (Salmo salar) (6), and, in 1990, major losses were recorded among the Atlantic salmon cultured in southern Chile. Chinook salmon (Oncorhynchus tshawytscha) and rainbow trout (Oncorhynchus mykiss) held at saltwater rearing sites also experienced mortality attributed to this agent. The disease does not occur in these stocks of fish during the freshwater-rearing phase of their life cycle, but mortality begins 6 to 12 weeks after introduction into seawater.

Diseased fish are lethargic, anemic, and dark in color. Hematocrits fall to $27 \%$ or less. The kidney is swollen; the spleen is enlarged, and occasionally gray, mottled lesions are present in the liver (1). Hematopoietic tissues exhibit extensive necrosis, and microorganisms morphologically similar to rickettsiae of the tribe Ehrlichieae can be observed by light and electron microscopy within membrane-bound cytoplasmic vacuoles or inclusions in tissues of the kidney and other internal organs (3).

In a comprehensive effort to determine the cause of the epizootics in coho salmon, tissues from diseased fish were collected for bacteriological, virological, and parasitological analysis. No known fish pathogens were identified in these preparations, but a microorganism morphologically identical to that observed in diseased fish was isolated from kidney tissues inoculated onto a chinook salmon cell line (CHSE214 [ATCC CRL 1681]) $(5,14)$.

To complete Koch's postulates and test the virulence of the bacterial isolate, 10 -fold dilutions of medium from an infected CHSE-214 cell culture were injected into juvenile Atlantic and coho salmon. Inoculated fish developed the

\footnotetext{
* Corresponding author. $\dagger$ Oregon Agricultural Experiment Station Technical Paper no.
9622.
}

disease, and mortality approached $100 \%$ in all injected groups. The onset of mortality followed a clear dose-response pattern, and the microorganism was reisolated in pure culture from fish in each experimental treatment (6).

Fryer et al. (5) suggested that this organism belongs in the order Rickettsiales, the family Rickettsiaceae, and the tribe Ehrlichieae on the basis of morphology and site of replication, but phenotypic characters alone were insufficient to determine specific placement. Therefore, we compared the 16 S rRNAs from LF-89 and other gram-negative bacteria to determine the phylogenetic position of this agent.

\section{MATERIALS AND METHODS}

Bacterial isolate. The isolate designated LF- 89 was utilized in characterization studies. It was cultured from a moribund 2-year-old coho salmon, ca. $40 \mathrm{~cm}$ in length and weighing ca. $1 \mathrm{~kg}$. The salmon, which displayed typical disease signs, was collected from a seawater netpen in southern Chile where an epizootic was in progress. Small fragments (ca. $1 \mathrm{~mm}^{3}$ ) of kidney tissue were aseptically removed from the fish and inoculated directly into $25-\mathrm{cm}^{2}$ tissue culture flasks (Corning Glass Works, Corning, N.Y.) containing a monolayer of CHSE-214 cells in antibiotic-free Eagle's minimum essential medium with Earle's salts (Automod; Sigma Chemical Co. St. Louis, Mo.) supplemented with $10 \%$ fetal bovine serum (Hyclone Laboratories, Inc., Logan, Utah). The cultures were kept at $4^{\circ} \mathrm{C}$ for transport to the Laboratory for Fish Disease Research, Oregon State University Hatfield Marine Science Center, Newport. Upon arrival, they were incubated at $15^{\circ} \mathrm{C}$ and observed for the appearance of cytopathic effect (CPE).

In the initial passage, CPE in the form of clusters of rounded cells appeared in the monolayer after 10 days of incubation at $15^{\circ} \mathrm{C}$. When $\mathrm{CPE}$ in the original cultures became extensive, an aliquot of spent medium was transferred to fresh monolayers of CHSE-214 cells to be incubated and observed. Characterization studies utilized subsequent cell culture passages of the agent.

Electron microscopy. Cultures prepared for transmission electron microscopy were grown in $25-\mathrm{cm}^{2}$ tissue culture flasks. After inoculation with strain LF-89, the CHSE-214 cells were incubated for 5 days at $15^{\circ} \mathrm{C}$. The medium was then decanted, and the cell sheet was washed three times with balanced salt solution and fixed in place with $2.5 \%$ 
glutaraldehyde (Sigma) in balanced salt solution. The cells were scraped from the flask and centrifuged at $1,000 \times g$ for $5 \mathrm{~min}$. The cell pellet was postfixed with osmium, dehydrated, and embedded in Spurr's embedding medium (26). The fixed cells were then sectioned, stained in Reynolds' lead citrate (20), and viewed with a Philips CM12/STEM electron microscope at $60 \mathrm{kV}$ in the transmission mode.

Cells to be viewed by scanning electron microscopy were plated on 15-mm-diameter round coverslips (Bellco Glass, Inc., Vineland, N.J.) placed in the wells of a 24-well, flat-bottom tissue culture plate (Corning). These cultures were inoculated and incubated at $15^{\circ} \mathrm{C}$, and at selected intervals, coverslips were removed and rinsed in balanced salt solution. After fixation in $2.5 \%$ glutaraldehyde, the cells were dried to the critical point, coated with $200-\mathrm{nm} \mathrm{Au}-\mathrm{Pd}$ (60:40, wt/wt), and viewed with an Amray 1000A scanning electron microscope operated at $20 \mathrm{kV}$.

Nucleic acid sequencing. Nucleic acids were prepared from a 5-ml culture of infected CHSE-214 cells by enzymatic digestion and extraction with phenol. Briefly, $3 \mathrm{ml}$ of lysis buffer (0.75 $\mathrm{M}$ sucrose, $400 \mathrm{mM} \mathrm{NaCl}, 20 \mathrm{mM}$ EDTA, $50 \mathrm{mM}$ Tris- $\mathrm{HCl}[\mathrm{pH} 9.0]), 0.2 \%$ sodium dodecyl sulfate, and $1 \mathrm{mg}$ of proteinase K (U.S. Biochemical Corp., Cleveland, Ohio) were added to a $25-\mathrm{cm}^{2}$ tissue culture flask containing infected CHSE-214 cells. The flask was incubated with gentle agitation for $1 \mathrm{~h}$ at $58^{\circ} \mathrm{C}$ to lyse the cells. The lysate was extracted twice with buffer-saturated phenol ( $\mathrm{pH}$ 8.0) and once with $\mathrm{CHCl}_{3}$. The nucleic acids were then precipitated from solution by the addition of 0.1 volume of $2 \mathrm{M}$ sodium acetate solution and 2 volumes of ethanol.

The polymerase chain reaction (PCR) was used to amplify eubacterial 16S rRNA genes from the infected culture $(7,22$, 23). Sequences of the amplification primers are indicated by lowercase letters in Fig. 1. The reaction mixture contained a $1 \mu \mathrm{M}$ concentration of each primer, a $200 \mu \mathrm{M}$ concentration of each deoxynucleoside triphosphate, $100 \mathrm{ng}$ of the nucleic acid sample, $1.0 \mathrm{U}$ of Taq polymerase (Promega, Madison, Wis.), and $1 \times$ PCR buffer (Promega) in a volume of $100 \mu \mathrm{l}$. Thirty-five cycles of amplification were performed, with each cycle consisting of $1 \mathrm{~min}$ at $95^{\circ} \mathrm{C}, 2 \mathrm{~min}$ at $60^{\circ} \mathrm{C}$, and 3 $\min$ at $72^{\circ} \mathrm{C}$

The amplified genes coding for rRNAs (rDNAs) were sequenced directly with universal small-unit rDNA primers $(11,24)$. Templates were prepared for sequencing by agarose minigel electrophoresis of the PCR mixtures and elution of the 16S rDNAs from excised gel fragments by adsorption to glass beads (27). The eluted DNA (ca. $1 \mu \mathrm{g}$ ) and $1.0 \mathrm{pmol}$ of sequencing primer in an $8-\mu l$ volume of water were heated to $95^{\circ} \mathrm{C}$ and snap frozen in a dry ice-ethanol bath. The frozen template was then allowed to slowly warm to $4^{\circ} \mathrm{C}$ and sequenced with a Sequenase kit (U.S. Biochemical) and $\left[\alpha-{ }^{35}\right.$ S $]$ dATP.

The sequence data were analyzed on a MicroVAX II computer (Digital Equipment Corporation, Andover, Mass.) using the VMS operating system. Manual sequence alignment, evolutionary distance calculations, and phylogenetic tree inference were performed with the software package SEQED.

Nucleotide sequence accession number. The sequence generated in this study appears in the EMBL data base under accession number X60783.

\section{RESULTS AND DISCUSSION}

Fryer et al. (5) suggested that the organism isolated from coho salmon was a member of the order Rickettsiales, although few rickettsiae have been found in association with fish and no fish disease of confirmed rickettsial etiology has previously been reported. A review by Wolf (30) of the chlamydiae and rickettsiae of fish cites as the only example of rickettsiae an unconfirmed case report from Egypt in 1939 of small coccoid forms, staining pink with Giemsa stain, found within monocytes and in plasma of blood smears from a dead tetradonid fish. Ozel and Schwanz-Pfitzner (19) observed a rickettsialike agent morphologically different from LF-89 in cultured fish cells inoculated with tissue from rainbow trout infected with Egtved virus (viral hemorrhagic septicemia virus). Although mortality was observed in the trout population, the cause is unclear. The agent was not maintained (25), and no studies beyond microscopic observation were conducted to establish the rickettsial identity or to determine whether the observed organism was pathogenic for fish. Neorickettsia helminthoeca, the cause of the "salmon poisoning" disease of canids, is associated with fish but is not a fish pathogen. It is carried by a digenetic trematode, Nanophyetus salmincola, that is a parasite of salmonid fish in the Pacific Northwest (15), but replication in fish tissues has not been reported. Noonan (17) cultured the agent in cells of canine and murine origin but was unsuccessful in attempts to culture $N$. helminthoeca in cells originating from salmonid fish.

The LF-89 organism clearly belongs in the order Rickettsiales for the following reasons. (i) It is an obligately intracellular bacterium; numerous attempts at either primary isolation or passage of the cell culture isolate on bacteriological media were unsuccessful (5). (ii) It has a morphology common to certain rickettsiae, i.e., the ehrlichiae, and to the reticulate bodies of the chlamydiae (16), but it does not fit within the order Chlamydiales because, although pleomorphic, it does not exhibit the alternating morphological forms observed with chlamydial organisms and does not react with a monoclonal antibody against the chlamydial genus-specific lipopolysaccharide antigen (5).

Precise taxonomic placement of the agent from coho salmon was difficult. Although it is morphologically similar to organisms in the tribe Ehrlichieae of the family Rickettsiaceae and has the most common feature of this group, i.e., replication within membrane-bound cytoplasmic inclusions in host cells (21), host specificity and serological characteristics suggest that it does not fit in any of the established genera. Previously characterized ehrlichial agents are pathogens of mammals (21); this agent is the pathogen of a poikilotherm and replicates optimally in fish cell cultures incubated between 15 and $18^{\circ} \mathrm{C}(5)$, but no replication occurs at temperatures above $25^{\circ} \mathrm{C}$. It possesses few antigens in common with the ehrlichial agents with which it was compared. A very low-level reaction was noted by Lannan et al. (12) when LF-89 was tested with canine granulocytic Ehrlichia antiserum by indirect immunofluorescence, but no reaction was apparent with antiserum against Ehrlichia equi, Ehrlichia canis, or $N$. helminthoeca. However, small-subunit rRNA sequence comparisons now play a crucial role in the resolution of problems in bacterial taxonomy, particularly in cases where phenotypic characters are insufficient to demonstrate close evolutionary relationships among species.

Weisburg and coworkers (28) used rRNA sequence comparisons to demonstrate that the family Rickettsiaceae is polyphyletic. Representatives of the genus Rickettsia were found to form a monophyletic cluster within the alpha subdivision of the class Proteobacteria. Sequence comparisons indicated that Ehrlichia risticii was also a member of the alpha subdivision but was not specifically related to the 


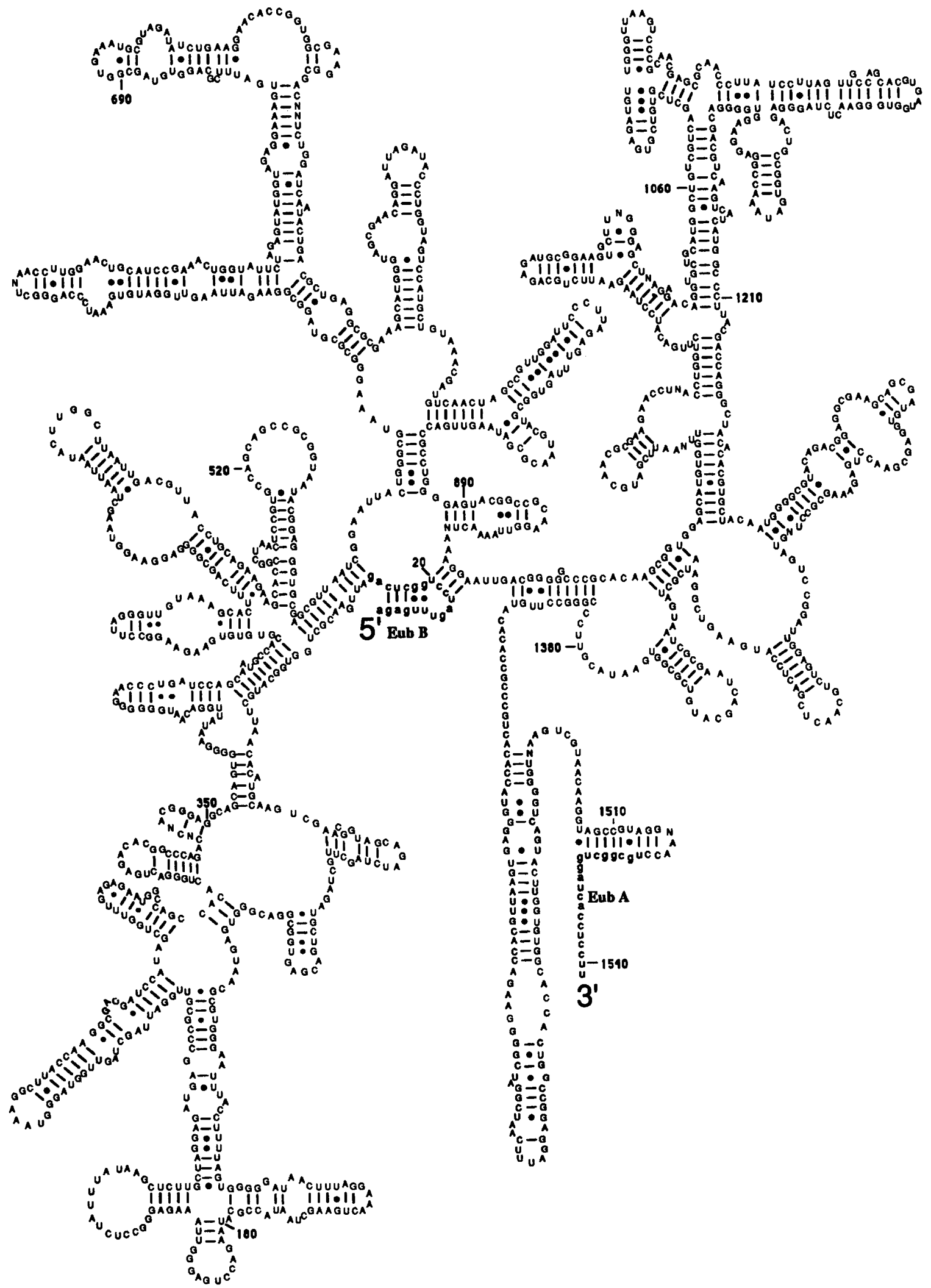

FIG. 1. The 16S rRNA gene sequence of Piscirickettsia salmonis, shown folded according to the secondary structural model of Gutell et al. (9). Numbering corresponds to that of the Escherichia coli 16S rRNA (2). 


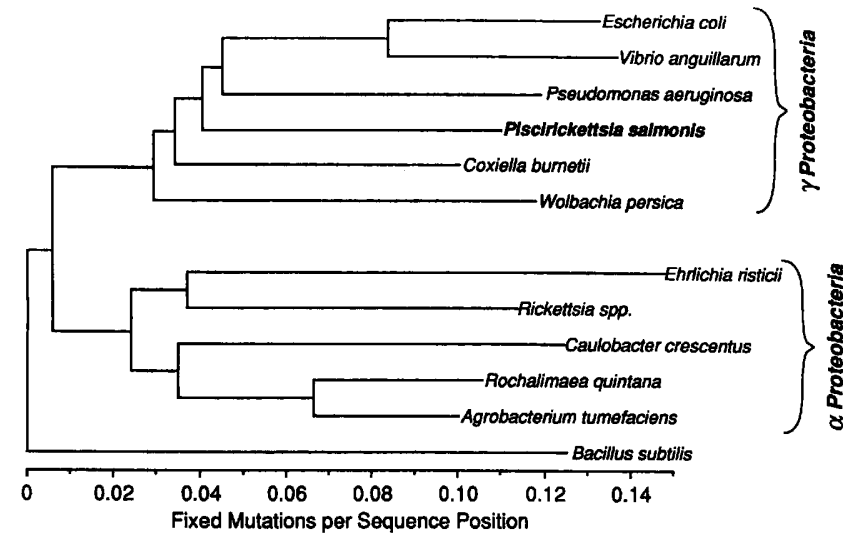

FIG. 2. Phylogenetic tree showing relationships between Piscirickettsia salmonis and representative members of the alpha and gamma subdivisions of the Proteobacteria. Evolutionary distances were calculated by the method of Jukes and Cantor (10). Approximately 1,200 positions were included in the analysis. The tree was calculated by a distance matrix method (18). The sequences other than that of $\boldsymbol{P}$. salmonis are from a report by Weisburg et al. (28) and the EMBL data base.

genus Rickettsia. Coxiella burnetii, the causative agent of $\mathrm{Q}$ fever, and Wolbachia persica, a commensal of ticks, were both found to be gamma proteobacteria. $C$. burnetii and $W$. persica were not specifically related to each other. Collectively, these phylogenetic data suggest at least five independent origins for intracellular parasites.

We determined the LF-89 16S rRNA sequence by directly sequencing genes amplified from a mixed DNA population obtained from an infected CHSE-214 cell culture. Although the oligonucleotide primers used for the amplification were homologous to those of a broad range of eubacteria, direct sequencing indicated the presence of a single eubacterial gene.

The 16S rDNA sequence of LF-89 conformed to the secondary structural models for the gamma subdivision of the Proteobacteria (Fig. 1). This conclusion was further supported by the sequence similarities shown in Table 1 . The sequence from the salmonid pathogen showed no specific relationship to any of the 450 bacterial $16 \mathrm{~S}$ rRNA sequences found in the files of the rRNA Data Base Project (29). Furthermore, comparisons with the sequences of Rickettsia rickettsii, Rickettsia typhi, Rickettsia prowazekii, E. risticii, Rochalimaea quintana, W. persica, and C. burnetii indicated that LF-89, although more closely related to $W$. persica and $C$. burnetii (which are in the gamma subdivision of the Proteobacteria) than to members of the genera Rickettsia, Ehrlichia, and Rochalimaea (which are in the alpha subdivision), was not a specific relative of any of these intracellular bacteria.

Evolutionary relationships of the LF-89 16S rDNA are illustrated by the phylogenetic tree in Fig. 2. The unique 16S rRNA sequence, coupled with the temperature requirements, host range, and serological characteristics of this pathogen, warrants its classification as a new genus and new species in the family Rickettsiaceae. However, assignment to a tribe must be delayed until there is appropriate reclassification of the family. We suggest the establishment of a new genus, Piscirickettsia gen. nov. (Pis'ci.ric.kett'si.a.) L. n. piscis, fish; generic name Rickettsia; N.L. fem. n. Piscirickettsia, rickettsial organism affecting fish), for this organism and propose the species name Piscirickettsia salmonis gen. nov., sp. nov. (sal.mo'nis. L. gen. n. salmonis, of salmon), since it was first discovered in salmon.

Description of the genus Piscirickettsia gen. nov. Coccoid, ca. 0.5 to $1.5 \mu \mathrm{m}$ in diameter (Fig. 3 and 4), but often pleomorphic. Gram negative, retains basic fuchsin when stained by Pinkerton's method, and stains dark blue with Giemsa stain. Nonmotile. Sections show the wall profile of a gram-negative bacterium and the protoplasmic structure of a procaryote. Characteristically replicates within cytoplasmic vacuoles in susceptible fish host cells (Fig. 5). Cultivable in fish cell cultures but not in cell-free media. Sensitive to a broad range of antibiotics but not to penicillin. The causative agent of the disease piscirickettsiosis in fishes.

Description of the species Piscirickettsia salmonis gen. nov., sp. nov. Pleomorphic, predominantly coccoid, ca. 0.5 to 1.5 $\mu \mathrm{m}$ in diameter, but also occurs as rings or pairs of curved rods. Gram negative, nonmotile.

The organism is a pathogen of salmonid fishes and replicates by binary fission (Fig. 6) within membrane-bound cytoplasmic vacuoles or inclusions (Fig. 7) in cells of susceptible fish hosts or in fish cell lines (5), including CHSE214, CHH-1 (14), CSE-119 (14), and RTG-2 (31) from salmo-

TABLE 1. 16S rRNA sequence similarities between Piscirickettsia salmonis and other eubacteria

\begin{tabular}{|c|c|c|c|c|c|c|c|c|c|c|c|}
\hline \multirow[b]{2}{*}{ Species } & \multicolumn{11}{|c|}{$\%$ Similarity to ${ }^{a}:$} \\
\hline & $\begin{array}{l}\text { B. sub- } \\
\text { tilis }\end{array}$ & $\begin{array}{c}A . \\
\text { tume- } \\
\text { faciens }\end{array}$ & $\begin{array}{l}\text { C. cres- } \\
\text { centus }\end{array}$ & $\begin{array}{c}R . \\
\text { quin- } \\
\text { tana }\end{array}$ & $\underset{\text { risticii }}{E .}$ & R. typhi & E. coli & $\begin{array}{c}\text { V. anguil- } \\
\text { larum }\end{array}$ & $\begin{array}{c}P . \\
\text { aerugi- } \\
\text { nosa }\end{array}$ & C. burnetii & W. persica \\
\hline
\end{tabular}

Bacillus subtilis

Agrobacterium tumefaciens

Caulobacter crescentus

80.3

Rochalimaea quintana

Ehrlichia risticii

Rickettsia typhi

Escherichia coli

Vibrio anguillarum

Pseudomonas aeruginosa

Coxiella burnetii

Wolbachia persica

Piscirickettsia salmonis

$\begin{array}{ll}80.3 & \\ 80.5 & 86.3 \\ 80.6 & 93.1 \\ 77.3 & 82.6 \\ 79.4 & 84.7 \\ 79.5 & 80.9 \\ 78.3 & 80.5 \\ 80.4 & 81.8 \\ 81.0 & 83.6 \\ 79.8 & 82.5 \\ 78.4 & 83.0\end{array}$

85.2

78.2

78.2

$83.5 \quad 84.6 \quad 82.6$

$79.4 \quad 80.6$

$79.1 \quad 80.6$

$78.8 \quad 81.3$

$81.1 \quad 82.7$

$80.3 \quad 81.7$

$80.0 \quad 82.1$

\footnotetext{
${ }^{a}$ Regions of uncertain homology were eliminated from the comparison.
}

78.4
77.7

79.1

80.4

78.5

79.1
78.8
79.6
79.7
82.2
80.0
80.5

\section{5}

85.8

84.4

82.9

85.9
85.0

83.8

82.9 84.4

\section{6}

$83.6 \quad 84.7$

$\begin{array}{ll}83.6 & 84.7 \\ 86.8 & 87.5\end{array}$ 

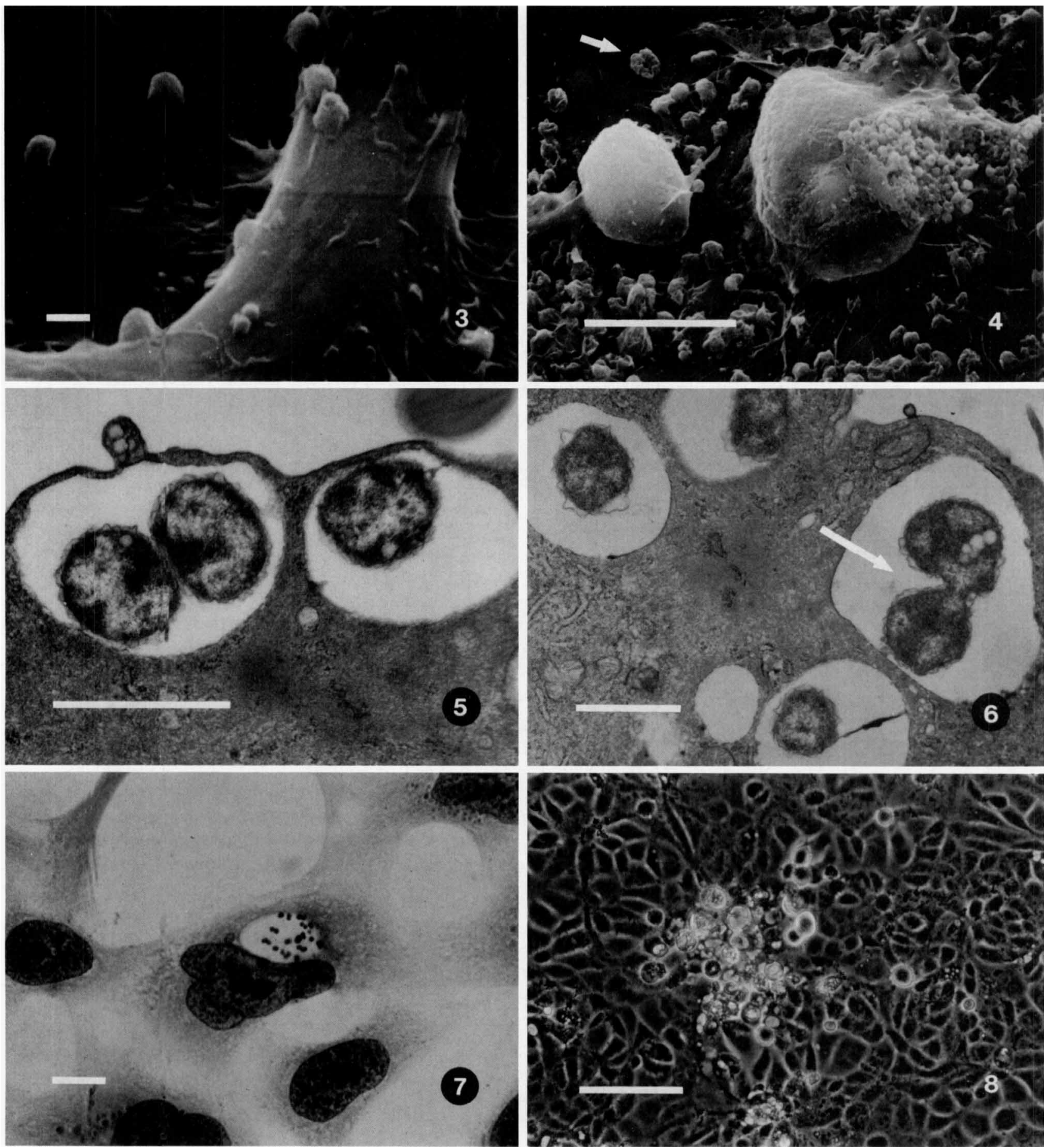

FIG. 3. and 4. Scanning electron micrographs of CHSE-214 cells infected with $P$. salmonis (reprinted from reference 5 with permission of the publisher). In Fig. 3, at $24 \mathrm{~h}$ postinoculation, $P$. salmonis organisms of various sizes are attached to the exterior surfaces of the host cells. Bar $=1 \mu \mathrm{m}$. In Fig. 4 , at 8 days postinoculation, the newly replicated organisms are being released from ruptured host cells. Note the ring form (arrow) and the varied sizes among the coccoid forms. Bars $=10 \mu \mathrm{m}$.

FIG. 5. and 6. Ultrathin sections of $P$. salmonis within membrane-bound cytoplasmic vacuoles in cultured CHSE-214 cells. One of the organisms in Fig. 6 is undergoing binary fission (arrow). Bars $=1 \mu \mathrm{m}$. Reprinted from reference 5 with permission of the publisher.

FIG. 7. P. salmonis in a cytoplasmic vacuole in a CHSE-214 cell 3 days postinoculation (May-Grünwald-Giemsa stain). Bar $=10 \mu \mathrm{m}$. Reprinted from reference 5 with permission of the publisher.

FIG. 8. CPE produced in CHSE-214 cells by P. salmonis. The image was obtained through phase-contrast microscopy. Bar $=10 \mu \mathrm{m}$ Reprinted from reference 5 with permission of the publisher. 
nid fishes and EPC (4) and FHM (8) from nonsalmonid fishes. In vitro replication is optimal between 15 and $18^{\circ} \mathrm{C}$, is greatly retarded at temperatures above $20^{\circ} \mathrm{C}$ and below $10^{\circ} \mathrm{C}$, and does not occur at or above $25^{\circ} \mathrm{C}$. The organism cannot be propagated in cell-free media.

$P$. salmonis has produced an epizootic disease with extensive mortality in four species of salmonids, $O$. kisutch, $O$. tshawytscha, O. mykiss, and $S$. salar, and no doubt other fish species are also susceptible. The disease has been experimentally induced in $O$. kisutch and $S$. salar by intraperitoneal injection of fluids from infected cell cultures (6), but the method of natural transmission has not been determined. It is likely that one or more species of marine poikilotherms serve as a reservoir of infection in the environment.

The organism is cytopathic (Fig. 8) and produces a titer of $10^{6}$ to $10^{7} 50 \%$ tissue culture infective doses per $\mathrm{ml}$ in cultured fish cells. The titer is reduced by $>99 \%$ by one freeze-thaw cycle at $-70^{\circ} \mathrm{C}$, but the presence of $10 \%$ dimethyl sulfoxide has a cryopreservative effect (5). The organism is sensitive to numerous antibiotics commonly used in cell culture or in human and veterinary medicine. In vitro replication is inhibited by low concentrations of gentamicin, streptomycin, erythromycin, rifampin, tetracycline, doxycycline, oxolinic acid, and chloramphenicol and is reduced by high concentrations of sulfamerazine but is unaffected by penicillin.

The recommended methods of detection are isolation in cell culture or microscopic observation of acridine orangestained tissue smears (13). Kidney tissue from infected fish is inoculated onto CHSE-214 cells cultured in antibiotic-free medium. The cultures are incubated at 15 to $18^{\circ} \mathrm{C}$ and observed for 21 to 28 days for the appearance of CPE. After detection in cell culture or by acridine orange stain, confirmatory identification of the organism is made by serological methods, e.g., fluorescent-antibody staining (12).

Description of the type strain. The type strain (LF-89) has been deposited with the American Type Culture Collection as strain ATCC(R) VR 1361. It is the first isolate of $P$. salmonis to be described (5).

\section{ACKNOWLEDGMENTS}

We thank the following individuals for valuable contributions to this project: L. H. Garcés, J. J. Larenas, and P. A. Smith of the University of Chile at Santiago for aid in the original isolation and characterization of the agent; Simon Sandino of the Association of Chilean Salmon Farmers for providing liaison with the salmonid growers of Chile; Gary Olsen of the University of Illinois at Urbana-Champaign for supplying the software package SEQED used in manual sequence alignment, evolutionary distance calculations, and phylogenetic tree inference; and T. O. MacAdoo of the Virginia Polytechnic Institute and State University for assistance in naming the organism.

This publication is the result, in part, of research sponsored by Oregon Sea Grant with funds from the National Oceanic and Atmospheric Administration Office of Sea Grant, Department of Commerce, under grant NA89AA-D-SG108, project R/FSD-14, and by the National Science Foundation under NSF grant BSR 8818167.

\section{REFERENCES}

1. Bravo, S., and M. Campos. 1989. Coho salmon syndrome in Chile. FHS/AFS Newsl. 17(3):3

2. Brosius, J., T. J. Dull, D. D. Sleeter, and H. F. Noller. 1981 Gene organization and primary structure of a ribosomal RNA operon from Escherichia coli. J. Mol. Biol. 148:107-127.

3. Cvitanich, J., O. Garate, and C. E. Smith. 1991. The isolation of a rickettsia-like organism causing disease and mortality in Chilean salmonids and its confirmation by Koch's postulate. J.
Fish Dis. 14:121-145.

4. Fijan, N., D. Sulimanovic, M. Bearzotti, D. Muzinic, L. O. Zwillenberg, S. Chilmonczyk, J. F. Vautherot, and P. de Kinkelin. 1983. Some properties of the Epithelioma papulosum cyprin (EPC) cell line from carp Cyprinus carpio. Ann. Virol. (Inst. Pasteur) 134E:207-220.

5. Fryer, J. L., C. N. Lannan, L. H. Garcés, J. J. Larenas, and P. A. Smith. 1990 . Isolation of a rickettsiales-like organism from diseased coho salmon (Oncorhynchus kisutch) in Chile. Fish Pathol. 25:107-114.

6. Garcés, L. H., J. J. Larenas, P. A. Smith, S. Sandino, C. N. Lannan, and J. L. Fryer. 1991. Infectivity of a rickettsia isolated from coho salmon (Oncorhynchus kisutch). Dis. Aquat. Org. 11:93-97.

7. Giovannoni, S. J. 1991. The polymerase chain reaction, p 177-203. In E. Stackebrandt and M. Goodfellow (ed.), Modern microbial methods: sequencing and hybridization techniques in bacteriological systematics. John Wiley \& Sons, Chichester, United Kingdom.

8. Gravell, M., and R. G. Malsburger. 1965. A permanent cell line from the fathead minnow (Pimephales promelas). Ann. N.Y. Acad. Sci. 126:555-565.

9. Gutell, R. R., B. Weiser, C. R. Woese, and H. F. Noller. 1985. Comparative anatomy of the 16S-like ribosomal RNA. Prog Nucleic Acid Res. Mol. Biol. 32:155-216.

10. Jukes, T. H., and C. R. Cantor. 1969. In H. N. Munro (ed.), Mammalian protein metabolism, p. 21-132. Academic Press, Inc., New York.

11. Lane, D. J., B. Pace, G. J. Olsen, D. J. Stahl, M. L. Sogin, and N. R. Pace. 1985. Rapid determination of $16 \mathrm{~S}$ rRNA sequences for phylogenetic analysis. Proc. Natl. Acad. Sci. USA 82:69556959.

12. Lannan, C. N., S. A. Ewing, and J. L. Fryer. A fluorescent antibody test for detection of the rickettsia causing disease in Chilean salmonids. J. Aquat. Anim. Health, in press.

13. Lannan, C. N., and J. L. Fryer. 1991. Recommended methods for inspection of fish for the salmonid rickettsia. Bull. Eur. Assoc. Fish Pathol. 11:135-136.

14. Lannan, C. N., J. R. Winton, and J. L. Fryer. 1984. Fish cell lines: establishment and characterization of nine cell lines from salmonids. In Vitro (Rockville) 20:671-676.

15. Milleman, R. E., and S. E. Knapp. 1970. Biology of Nanophyetus salmincola and "salmon poisoning" disease. Adv. Parasitol. 8:1-41.

16. Moulder, J. W. 1984. Order II. Chlamydiales Storz and Page 1971, 334 ${ }^{\mathrm{AL}}$, p. 729-739. In N. R. Krieg and J. G. Holt (ed.), Bergey's manual of systematic bacteriology, vol. 1. Williams and Wilkins, Baltimore.

17. Noonan, W. E. 1973. Ph.D. thesis. Oregon State University, Corvallis.

18. Olsen, G. J. 1988. Phylogenetic analysis using ribosomal RNA. Methods Enzymol. 164:793-812.

19. Ozel, M., and I. Schwanz-Pfitzner. 1975. Vergleichende elektronenmikroskopische Untersuchungen an Rhabdoviren pflanzlicher und tierischer Herkunft: III. Egtved-Virus (VHS) der Regenbogenforelle (Salmo gairdneri) und Rickettsienahnliche Organismen. Zentralbl. Bakteriol. Hyg. Abt. 1 Orig. 230:1-14.

20. Reynolds, E. S. 1963 . The use of lead citrate at high pH as an electron-opaque stain in electron microscopy. J. Cell Biol. 17:208-212.

21. Ristic, M., and D. L. Huxsoll. 1984. Tribe II. Ehrlichieae Philip $1957,948^{A L}$, p. 704-711. In N. R. Krieg and J. G. Holt (ed.), Bergey's manual of systematic bacteriology, vol. 1. Williams and Wilkins, Baltimore.

22. Saiki, R. K., D. H. Gelfand, S. Stoffel, S. J. Scharf, R. Higuchi, G. T. Horn, K. B. Mullis, and H. A. Erlich. 1988. Primerdirected enzymatic amplification of DNA with a thermostable DNA polymerase. Science 239:487-491.

23. Saiki, R. K., S. Scharf, F. Faloona, K. B. Mullis, G. T. Horn, H. A. Erlich, and N. Arnheim. 1985. Enzymatic amplification of beta-globin genomic sequences and restriction site analysis for diagnosis of sickle cell anemia. Science 230:1350-1354.

24. Sanger, F., S. Nicklen, and A. R. Coulson. 1977. DNA sequenc- 
ing with chain-terminating inhibitors. Proc. Natl. Acad. Sci. USA 74:5463-5467.

25. Schwanz-Pfitzner, I. (Robert Koch-Institut). 1990. Personal communication

26. Spurr, A. R. 1969. A low viscosity epoxy resin embedding medium for electron microscopy. J. Ultrastruct. Res. 26:3143.

27. Vogelstein, B., and D. Gillespie. 1979. Preparative and analytical preparation of DNA from agarose. Proc. Natl. Acad. Sci. USA 76:615-619.
28. Weisburg, W. G., M. E. Dobson, J. E. Samuel, G. A. Dasch, L. P. Mallavia, O. Baca, L. Mandelco, J. E. Sechrest, E. Weiss, and C. R. Woese. 1989. Phylogenetic diversity of the rickettsiae. J. Bacteriol. 171:4202-4206.

29. Woese, C. R. (University of Illinois). 1991. Personal communication.

30. Wolf, K. 1981. Chlamydia and rickettsia of fish. Fish Health News 10:1-5.

31. Wolf, K., and M. C. Quimby. 1962. Established eurythermic line of fish cells in vitro. Science 135:1065-1066. 